\title{
Fish Marketing of Ribbon Fish (Trichiurus sp.) in Nusantara Fishing Port (NFP)at Palabuhanratu, West Java
}

\author{
Azis Nur Bambang ${ }^{1, *}$ \\ Faculty of Fisheries and Marine Science, Diponegoro Univers ity,
}

\begin{abstract}
The objective of this research is to study the marketing process of ribbon fish (Trichiurus $s p$.), including the marketing margin, marketing agencies, traders and marketing channels The research was carried out for 3 mo in Nusantara Fishing Port (NFP), Palabuhanratu, Sukabumi, West Java. A case study was used in this research. A purposive sampling method was used to collect data from 55 respondents of fish marketing, consisting of fishermen, agents, traders, and retailers, who were involved in the marketing of ribbon fish in NFP Palabuhanratu. The result of the research showed that ribbon fish production in Palabuhanratu fluctuated from year to year. There are two types of ribbon fish marketing, i.e. type one is from fishermen to retailers, and type two is indirect marketing from fisherman to consumers through intermediate traders (exporters). The greatest marketing margin was obtained from the first type, while the smallest marketing margin was obtained from type two. The form of the market was considered to be oligopsony market. Fisherman's share is greatest in the collectors and the smallest share is on retailers. Marketing process in traders is efficient due to its lowest margin and highest fisherman's share.
\end{abstract}

\section{Introduction}

Sukabumi, West Java, is an area where most of it is directly adjacent to the Indian Ocean. Sukabumi regency has a coastline of $117 \mathrm{~km}$, and it has the Nusantara Fishery Port (NFP) located in Palabuhanratu district. The marine waters of Palabuhanratu is a potential and strategic area for fishing because of the great economic value from the captured fish in Nusantara Fishing Port [1]. One of the main commodities of fisheries is ribbon fish (Trichiurus sp.), tuna (Thunnus sp.), small tuna (Euthynnus sp.), snapper (Lutjanus sp.), and mackerel (Scomberromorus sp.).

Ribbon fish (Trichiurus sp.) is one of the major fish commodities in NFP Palabuhanratu. The amount of ribbon fish captured in NFP Palabuhanratu in 2014 was $61560 \mathrm{~kg}$ and production value of IDR 1.546299 $\times 10^{9}$ [2]. Ribbon fish in NFP Palabuhanratu was captured using stretching and longline fishing method. The total production was abundant, thus, requiring a good marketing to distribute the fish to consumers in the form of fresh and processed fish.

\section{Materials and Methods}

Respondents used in this study were the subjects of ribbon fish marketing, consisting of fishermen, agents, traders, wholesaler and retailers. Descriptive analysis method was used in this research, and followed by the implementation using survey techniques [3]. The data were collected to describe the marketing of ribbon fish in NFP Palabuhanratu succinctly and objectively.

Purposive sampling and snowball sampling method used in this research. The primary data and secondary data were used. Samples of respondents consist fishermen, wholesalers, agencies, and ribbon fish retailers (Table 1).

Table 1. Respondents sample

\begin{tabular}{|c|l|c|}
\hline No. & Respondents & Sample \\
\hline 1. & Fishermen & 30 \\
\hline 2. & Wholesaler & 5 \\
\hline 3 & Agent & 10 \\
\hline 4. & Retailer & 10 \\
\hline Total & & 55 \\
\hline
\end{tabular}

${ }^{*}$ Corresponding author azis_undip2013@yahoo.com 
Technical data analysis methods of the fishing by a descriptive analysis, such as value and production of ribbon fish and ribbon fish fishing areas [4]. Marketing data processed by marketing margin analysis, including costs and benefits as well as fisherman share were analyzed. Analysis of the advantages of each marketing agency is based on the following formula [5]:

$$
\pi=T R-T C
$$

$\pi=$ Profit (IDR), $\mathrm{TR}=$ Total Revenue (IDR) and TC $=$ Total cost (IDR).

Marketing margin analysis was used to determine the distribution of the costs and benefits of any intermediaries as well as parts of prices received by producers. Marketing margin analysis was also used to determine the level of competence of the subjects involved in the marketing of fish distribution. Marketing margin can be calculated as follows [6] :

$$
M m=P e-P f i
$$

$\mathrm{Mm}=$ Marketing Margin $\quad\left(\mathrm{IDR} \cdot \mathrm{kg}^{-1}\right), \mathrm{Pe}=$ Price on seller $\left(\mathrm{IDR} \cdot \mathrm{kg}^{-1}\right)$ or selling price,

$\mathrm{Pf}=$ Price on producer $\left(\mathrm{IDR} \cdot \mathrm{kg}^{-1}\right)$ or purchasing price.

The average net profit per day from marketing agencies can be obtained by the following formula [7]:

$$
M=B+\pi
$$

$\mathrm{M}=$ Marketing Margin (IDR $\left.\cdot \mathrm{kg}^{-1}\right), \mathrm{B}=$ Cost $($ IDR . $\mathrm{kg}^{-1}$ ) and

$\pi=$ Profit market seller $\left(\mathrm{IDR} \cdot \mathrm{kg}^{-1}\right)$.

To determine the efficiency of marketing in any involved marketing agencies, the following formula was used [7]:

$$
E p=\frac{\text { Marketing } \cos t}{\text { Value of marketing product }}
$$

The marketing cost is in IDR $\cdot \mathrm{kg}^{-1}$, and the value of marketing product is in IDR $\cdot \mathrm{kg}^{-1}$. If the Ep value $>1$, the marketing process is not efficient, whereas if Ep value $<1$, the process is efficient.

Fishermen's share analysis can be formulated as follows:

$$
F=\frac{H n}{H k} \quad 100 \%
$$

in which $\mathrm{F}=$ shares received by fishermen (\%), $\mathrm{Hn}=$ price of ribbon fish at fishermen level (IDR $\left.\cdot \mathrm{kg}^{-1}\right)$ and $\mathrm{Hk}=$ price of ribbon fish at consumer level $\left(\mathrm{IDR} \cdot \mathrm{kg}^{-1}\right)$

Table 2. Value and production of ribbon fish, periode 2010 to 2014

\begin{tabular}{|c|c|l|r|}
\hline No & Year & $\begin{array}{l}\text { Production } \\
(\mathbf{k g})\end{array}$ & Value (IDR) \\
\hline 1 & 2010 & 36730 & 556035500 \\
\hline 2 & 2011 & 147864 & 2114744500 \\
\hline 3 & 2012 & 185914 & 3420045200 \\
\hline 4 & 2013 & 83936 & 1750018000 \\
\hline 5 & 2014 & 61560 & 1546299000 \\
\hline
\end{tabular}

Source : NFP, Palabuhanratu [2]
According to Maisaroh fishermen's share is the share of the fishermen (producer), in which the greater the fishermen's share, the smaller the marketing margin, thus, marketing distribution runs efficiently [8].

\section{Results and Discussion}

\subsection{Overview}

The Nusantara Fishery Port (NFP) Palabuhanratu is one of the five regional fishery ports converted into industrialization of fisheries. NFP Palabuhanratu is selected as a base or center for fisheries management for economic development, i.e. creation of jobs and public revenues through the reform of fisheries business service centers that functions to serve, encourage, and stimulate regional development of fisheries in West Java. Ribbon fish (Trichiurus sp.). as a dominant fish commodities at NFP o.

Trichiurus sp. is one of the leading commodity fish in NFP Palabuhanratu. Ribbon fish production in Palabuhanratu fluctuated from year to year. Table 2 shows the production of ribbon fish in Palabuhanratu NFP from 2010 to 2014. According to the Table 2, from 2010 to 2014, ribbon fish production continued to fluctuate because of the uncertain weather and unstable fishing season. Some factors that influence the success of ribbon fish fishing are season, weather and oceanographic condition. Production and price of ribbon fish in NFP Palabuhanratu is fluctuative each month depending on fishing season (Table 3 ).

Production of ribbon fish in NFPPalabuhanratu fluctuated every month. The supply fluctuation does not particularly affect the price. Price of ribbon fish depends on the agreement between sellers and buyers (retailers and collectors), not on season and supply.

\subsection{Fishermen / Producer Ribbon Fish}

Ribbon fish production in NFP Palabuhanratu using fiber boats was given a booster in the form of wood. Ribbon fish fishing boat was operated by two or three crews within $1 \mathrm{~d}$ of fishing. The average trip of ribbon fish fishing boat is 175 trip each year. The boat uses an engine of $5.5 \mathrm{hp}$ (horsepower) [1 hp = 746 W]. Ribbon fish fishing gear consists of a spindle, main rope, swivel, rope branches, rods, weights, wireleader, and hook.Ribbon fish fishing is usually done during the day or night, at 4:00 a.m. to 15:00 noon, or at 4:00 p.m. to 7:00 a.m. Fishing ground area is located around Palabuhanratu gulf which is determined based on the experience of fishermen in the previous fishing activities. 
Table 3. Production, value, and price of ribbon fish at Palabuhanratu in 2014

\begin{tabular}{|l|r|r|r|}
\hline Month & \multicolumn{1}{|l|}{$\begin{array}{l}\text { Produc- } \\
\text { tion } \\
\text { (kg) }\end{array}$} & $\begin{array}{l}\text { Value } \\
\text { (IDR) }\end{array}$ & $\begin{array}{r}\text { Price } \\
\text { (IDR) }\end{array}$ \\
\hline January & 3982 & 109675000 & 27543 \\
\hline February & 3746 & 92747000 & 24759 \\
\hline March & 28108 & 702700000 & 25000 \\
\hline April & 11917 & 296040000 & 24842 \\
\hline May & 4237 & 105925000 & 25000 \\
\hline June & 904 & 22600000 & 25000 \\
\hline July & 716 & 17900000 & 25000 \\
\hline August & 624 & 15562000 & 24939 \\
\hline September & 1293 & 32325000 & 25000 \\
\hline October & 1428 & 35700000 & 25000 \\
\hline November & 2485 & 62125000 & 25000 \\
\hline December & 2120 & 53000000 & 25000 \\
\hline
\end{tabular}

Source: Annual Report Palabuhanratu NFP, 2014 [2]

USD $1=$ IDR 12287

Table 4. Revenues, expenses and profits of fishermen per trip

\begin{tabular}{|l|l|c|}
\hline No & Items & $\begin{array}{l}\text { Total (IDR } \\
\text { per day) }\end{array}$ \\
\hline 1 & Revenues & 325000 \\
\hline 2 & Expenses & \\
\hline & - depreciation cost & 12500 \\
\hline & - maintenance cost & 6600 \\
\hline & - operational cost & 120000 \\
\hline & Total cost & 139100 \\
\hline 3 & Profits & 185900 \\
\hline
\end{tabular}

USD 1 = IDR 12287

The total expense of ribbon fish fishing which consists of fixed costs and variable costs is quite low because it takes only one day for fishing and the number of crew is only two or three people. Average catch of ribbon fish is $10 \mathrm{~kg}$ in each trip. Revenues, expenses and profits of fishermen per trip are presented in Table 4.

\subsection{Agent/ Seller}

An agent is a person who mediates fishermen by middlemen. After fishing operation is completed, fishermen land their catch in NFP Palabuhanratu. The ribbon fish are not sold in auction, but directly sold by agent to collectors. Due to cooperation between fishermen and seller agents, the ribbon fish are not sold directly to collectors, but it has to be through seller agent.

Contact between fisherman and seller agent occurs because not all fishermen are able to finance operational costs which make them borrow fishing supplies such as fuel, ice blocks, oil, etc. from agents. Thus, in return, fishermen have to sell their catch through the agency.

Ribbon fish agents can earn $10 \%$ of total sales revenue and they can sell $47.5 \mathrm{~kg}$ of ribbon fish each day. The determination of selling price of ribbon fish is based on agreement between the agent and traders. In this study, average selling price of ribbon fish is IDR $32500 \cdot \mathrm{kg}^{-1}$. An average commission sales for agents is about IDR 155000 per day.

\subsection{Wholesaler/ Collector}

Traders require substantial capital investment. They have to purchase ribbon fish through an agent. Ribbon fish in traders are subsequently distributed to some industrial fisheries in the region of Palabuhanratu, i.e. PT. AGB Palabuhanratu, Duta Ratu, and Jaya Mitra, to be sent to Jakarta and surrounding areas, then exported. Besides industries, collectors also sell the fish to retailers or small traders. The size of the fish are divided into small (100 g to $250 \mathrm{~g}$ ), and large (over 250 g). Usually, large fish are sold to industries, while the small size fish are sold to retailers.

The price of fish from the agent is between IDR 30 $000 \cdot \mathrm{kg}^{-1}$ to IDR $35000 \cdot \mathrm{kg}^{-1}$. The average price of fish purchased from sellers is IDR 32500 and then resold for IDR 42500 . Below is a table of revenues, expenses and profits earned by wholesalers each day.

Table 5. Revenues, expenses and profits earned by wholesaler per day

\begin{tabular}{|c|l|r|}
\hline No & Items & Total (IDR) \\
\hline 1 & Revenue & 2720000 \\
\hline 2 & Cost & \\
\hline & - operational cost & 60000 \\
\hline & - material cost & 2080000 \\
\hline & - Total cost & 2130000 \\
\hline 3 & Profit & 580000 \\
\hline
\end{tabular}

USD 1 = IDR 12287

\subsection{Retailer}

Retaillers in PPN Palabuhanratu buy ribbon fish by skipping the service from agents. Profit obtained by retailer is quite big, because no transportation expense is needed. Consumers come directly to retailer sale outlet around the Fish Auction Place.

Table 6. Revenues, expenses and profits earned by retailer

\begin{tabular}{|l|l|c|}
\hline No & Item & Total (IDR) \\
\hline 1 & Revenues & 618750 \\
\hline 2 & Expenses & \\
\hline & - depresiation cost & 30000 \\
\hline & - maintenance cost & 406250 \\
\hline & - Total Cost & 436250 \\
\hline 3 & Profit & 182500 \\
\hline
\end{tabular}

USD 1 = IDR 12287 


\subsection{Consumer}

Ribbon fish marketing stops at final consumer level. Ribbon fish is not only marketed to local merchants but also for export commodities. Ribbon fish is quite attractive for consumers overseas.

Export of fish ribbon fish is done by a fish processing company in Indonesia. Consumers expect ribbon fish with low price and good quality. The average price of local ribbon fish at the consumer level is IDR $45000 \cdot \mathrm{kg}^{-1}$.

\subsection{Marketing Distribution}

First type of ribbon fish marketing channels is from fishermen to retailers and then to consumers, the distribution of fishery products to the distribution of semi-direct [9]. The size of ribbon fish marketed in type 1 is smaller, i.e. below $250 \mathrm{~g}$, but there are also some fish weighing above $250 \mathrm{~g}$. Sales percentage of ribbon fish at retailer level is lower than in traders, because retailers do not have much capital, thus the volume of buying and selling is also low. Retailers in this type of marketing channels sell their fish at the stalls of NFP Palabuhanratu.

Meanwhile, for marketing type 2, distribution of ribbon fish is from fisherman to agents, continued to traders, then to PT. AGB, exporters and consumers as the final chain. Fish marketing distribution channel is called the distribution of fishery products to the indirect distribution [9]. Ribbon fish that are sent to PT. AGB are stored in cold storage. The fish commodity is then distributed to exporters in Jakarta and surrounding areas (Figure 1) after fulfilling exporter's demand.

\subsection{Marketing Margin and Profit}

Margin is the difference between selling price and purchasing price at the marketing agency. The marketing margin when ribbon fish in which the fish are distributed from the fishermen to retailers in marketing type 1 is IDR $12500 \cdot \mathrm{kg}^{-1}$.

Highest marketing margin is IDR $12500 \cdot \mathrm{kg}^{-1}$ and obtained during distribution from fisherman to retailers in marketing type 1

The high margin value is influenced by the operational costs spent by retailers only to purchase ice cubes and plastic, buyers will come to their own kiosk retailers in NFP Palabuhanratu. Besides retailers market ribbon fish directly to consumers.

Ribbon fish price at consumer level ranges between IDR $40000 \cdot \mathrm{kg}^{-1}$ to IDR $50000 \cdot \mathrm{kg}^{-1}$. In the marketing channel type 2 , the marketing margin (IDR $10000 \cdot \mathrm{kg}^{-1}$ ) is lower than the marketing channel type 1. PT. AGB has determined the price between IDR $40000 \cdot \mathrm{kg}^{-1}$ to IDR $450000 \cdot \mathrm{kg}^{-1}$, on the other hand there is also a transportation cost for mobilization to PT. The greatest marketing profit is obtained by retailers in distribution type 1 . Retailers have high marketing profit because retailers have greater marketing margin than collector or wholesaler.

The high margin value is influenced by how much profit can be obtained by retailers and marketing costs, such as exposure margin above, retailers do not require transportation cost and the selling price to the consumer of fish is between IDR $50000 \cdot \mathrm{kg}^{-1}$ to IDR $40000 \cdot \mathrm{kg}^{-1}$

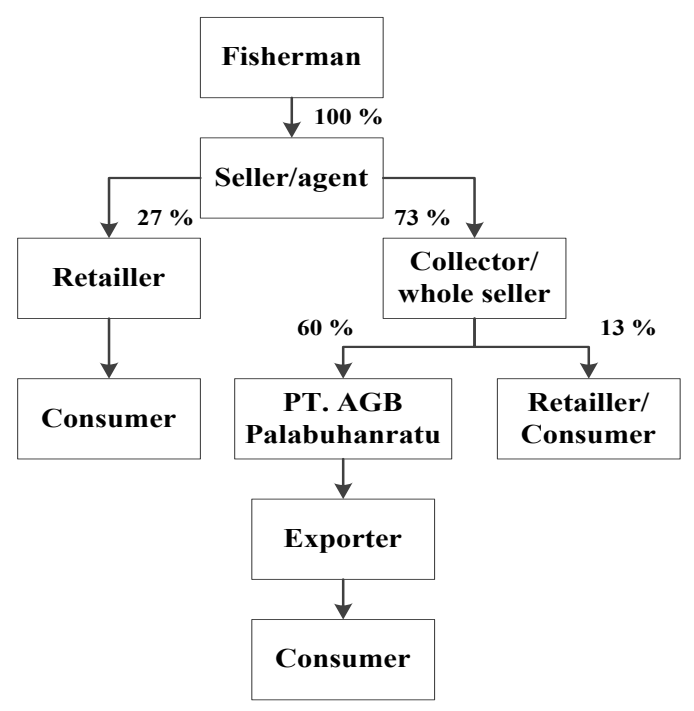

Fig. 1. Marketing distribution of ribbon fish at NFP Palabuhanratu

\subsection{Marketing Efficiency and Fisherman's Share}

Analysis of ribbon fish marketing efficiency was performed by counting marketing costs (IDR $\cdot \mathrm{kg}^{-1}$ ) compared to the price (IDR $\cdot \mathrm{kg}^{-1}$ ) of ribbon fish in the marketing chain. Marketing efficiency in the distribution of type 1 or type 2 value is $<1$, therefore, both types are efficient [7].

From the two distribution types, the most efficient distribution is obtained by traders with efficiency values of 0.02 , which is smaller than the value of efficiency at retailers $(0.05)$. In addition to using efficiency value, marketing efficiency can also be seen from the number of fisherman's share. The biggest fisherman's share is on trader, i.e., $76.5 \%$. This value is the share that is obtained by the fisherman. This value also represents the amount of fisherman influence towards the price. Moreover, fisherman's share in the retailer is $72.2 \%$ (Table 8 ). According to Maisaroh et al., smaller marketing margin means that distribution to the market runs efficiently [8]. 
Table 7. Marketing margin (IDR $\cdot \mathrm{kg}^{-1}$ ) of ribbon fish at NFP Palabuhanratu

\begin{tabular}{|c|c|c|c|c|c|c|}
\hline $\begin{array}{c}\text { Distribution } \\
\text { type }\end{array}$ & $\begin{array}{l}\text { Marketing } \\
\text { institution }\end{array}$ & $\begin{array}{c}\text { Paying } \\
\text { price } \\
\left(\mathrm{IDR} \cdot \mathbf{k g}^{-\mathbf{1}}\right)\end{array}$ & $\begin{array}{l}\text { Selling price } \\
\left(\mathrm{IDR} \cdot \mathrm{kg}^{-1}\right)\end{array}$ & $\begin{array}{c}\text { Margin } \\
\left(\mathrm{IDR} \cdot \mathrm{kg}^{-}\right. \\
\left.\mathbf{1}^{-}\right)\end{array}$ & $\begin{array}{c}\text { Marketing } \\
\text { Cost (IDR } \\
\left.\mathrm{kg}^{-1}\right)\end{array}$ & $\begin{array}{l}\text { Marketing } \\
\text { profit } \\
\text { (IDR) }\end{array}$ \\
\hline \multirow[t]{2}{*}{1} & Agent & & 32500 & & & \\
\hline & Seller (Retailler) & 32500 & 45000 & 12500 & 2400 & 10100 \\
\hline \multirow[t]{2}{*}{2} & Agent & & 32500 & & & \\
\hline & $\begin{array}{l}\text { Seller } \\
\text { (Wholesaler) }\end{array}$ & 32500 & 42500 & 10000 & 937 & 9063 \\
\hline
\end{tabular}

USD 1 = IDR 12287

While according to Dewayanti, the high margin is usually used as an indicator of the inefficiency of a marketing system, however, this is not always right [10]. By comparing fisherman's share, efficiency of a marketing system for fishery commodities can be determined. Therefore, the most efficient marketing agencies are traders because the margin are low and the fisherman's share is the greatest.

\section{Conclusion}

There are two types of ribbon fish marketing, i.e. type one is from fishermen to retailers, and type 2 is indirect marketing from fisherman to the consumer through intermediate traders (exporters). The greatest marketing margin is obtained from type 1 , while the smallest marketing margin is obtained in type 2 . The structure of the market is oligopsony market.

Fisherman's appearance has a market share which is greatest in the collectors and Fisherman's smallest share is on retailers. Marketing process in traders is efficient due to its lowest margin and highest fisherman's share. The market structure is oligopsony. To avoid domination from buyers. (oligopsony), fish distribution from fisherman directly to fish auction place is recommended.

\section{References}

1. Sudrajat, S.M. Nurul, A. Rosyid and A. N. Bambang, Journal of Fisheries Resources Utilization Management and Technology 3 (III). 141-19, (2014) [in Bahasa Indonesia].
2. Pelabuhan Perikanan Nusantara (PPN) Palabuhanratu, Laporan Tahunan Pelabuhan Perikanan Nusantara Palabuhanratu Tahun 2013. Direktorat Jenderal Perikanan Tangkap Kementerian Kelautan dan Perikanan.[Annual Report of Nusantara Fishing Port Palabuhanratu 2013. Jakarta: Ministry of Marine Affairs and Fisheries, (2014).

3. S.F. Shalichaty, A. K. Mudzakir, and A. Rosyid, Journal of Fisheries Resources Utilization Management and Technology, 3(3), 37-43, (2014). [in Bahasa Indonesia].

4. I.M. Wirartha, Economic social research methodologies. Yogyakarta: Andi Offset, (2006).

5. T. Nurasa, dan V. Darwis, Jurnal Akta Agrosia, 10(10), 40-48, (2007). [in Bahasa Indonesia].

6. A. Supriatna, (Study case in Cirebon district, West Java)].Agrin, 14(2), 97-113, (2010). [in Bahasa Indonesia].

7. N. Rasuli, M. A. Saade, and K. Ekasari, Agrisistem Journal, 3(1), 36-43, (2007). [in Bahasa Indonesia].

8. N. Maisaroh, Ismail, and H. Boesono, Journal of Fisheries Resources Utilization Management and Technology, 3 (3), 131-140, (2014). [in Bahasa Indonesia].

9. N. Rahardi, and K. Regina, Agribisnis perikanan [Fisheries agribusiness]. Jakarta: Penebar Swadaya Press, (2001). [in Bahasa Indonesia].

10. N.C. Dewayanti, Analisis Pemasaran Ikan Laut Segar di Kabupaten Cilacap. [Marketing Analysis of Marine Fish in Cilacap District] Universitas Sebelas Maret, Surakarta, (2003). 